リハビリテーション医療・福祉分野における近未来ロボット技術のインパフト

座長 田中 繁・伊藤 良介

\title{
6. マイクロマシンの応用
}

テルモ(株) 研究開発センター 大森繁

1.はじめに

ここ 10 年程の間に, マイクロマシンという言葉が広く一般に知られるようになってきた. 昨年終了した経済産業省（旧通産省）プロジェクトの影響もあるが，より微細でファインな 技術に産業界が活路を見出していこうという傾向が現実味を帯びてきているのは事実であり， 最近ではマイクロを通り越してナノテクノロジーへ話題が集中している．ナノの領域までい くと, 量子効果が発現される超微粒子を中心とした世界にまで論が及び, メカニクスという 概念から遠ざかるのでここでは触れないことにし，テクノロジーとしてのマイクロマシンと 医療・福祉との関わりについて述べる.

2. 医療・福祉分野におけるマイクロマシン

一般的にマイクロマシン技術と呼ばれているものは大きく2つのカテゴリーに分けられる. 1つは，文字通りミニチュアのマシンを作る技術であり，もう一つは半導体製造技術を中心 とした微細加工の技術である. 前者については, 微小ロボットのようなものが容易にイメー ジされ，医療・福祉への応用も古くから議論されてきたが，エネルギー供給の問題や発生力 の点から考えると, 例えミリサイズのものであっても単独ロボットの実現は極めて困難と言 わざるを得ない．定義を少し広げて，マイクロメカニクスという捉え方をするのであれば， 近年話題となっている内視鏡下手術用ロボットの手の部分がこれに該当してくる.ミリサイ ズの把持部を有するこのロボットハンドは, 狭空間で発揮されるミクロンオーダーの位置決 め能力により正確な手術を行うことができるため, 患者に対する侵襲度を小さくでき, 術後 のリハビリ期間の短縮に貢献できる.

一方, 微細加工技術に関しては, 半導体技術を利用したチップ状センサーの実用化が近年 急速に進んでおり, 圧力センサや加速度センサ, 新しいところではバイオチップ等が製品化 されている.また，こうした半導体技術に限らず，微細な加工技術を利用していけば，埋め 込み型の神経刺激ユニット等の実現も可能であり，オーストラリアの企業により微小電極を 有する人工内耳が既に製品化されている. 今後, この領域が更に進展していけば, 人工網膜 等のより高度な機能代替デバイスの実現も可能になると考えられる。また，こうした微小デ バイスを人体に埋め込む際には, 先のロボットハンドによる正確な手術が必須条件となるこ とが予想され，そのロボットハンドには，触覚等をフィードバックするための微小センサを 装着することまで考えていくと，マイクロマシン技術が果たす役割は今後益々大きくなるも のと考えられる。

3.おわりに

マイクロマシンというと，映画「ミクロの決死圈」で描かれたような単独で仕事をする微 小マシンを連想しがちであるが，実際には普段目にしている技術のなかにもその要素は既に 取り入れられており，リハビリテーション医療・福祉との関わりにおいても，今後より重要 性を増していくものと考えられる。 